\title{
PENERAPAN MODEL PEMBELAJARAN KOOPERATIF TIPE THINK PAIR SHARE (TPS) UNTUK MENINGKATKAN HASIL BELAJAR FISIKA PADA SISWA KELAS XI IPA3 SMA NEGERI 001 TAMBUSAI UTARA TAHUN PELAJARAN 2014/2015
}

\author{
RUBIATUN \\ Guru SMA N 001 Tambusai Utara Rokan Hulu
}

\begin{abstract}
ABSTRAK
Hasil belajar sisika siswa kelas XI IPA 3 SMA Negeri 1 Tambusai Utara, belum menunjukkan hasil yang maksimal. Terbukti hasil ulangan harian masih rendah, dari 26 siswa hanya 13 siswa $(50 \%)$ yang mendapat nilai mencapai KKM yang ditetapkan yakni 70 . Salaha satu rendahnya hasil belajar sisika, adalah sebagai besar (75\%) siswa tidak dapat menjawab soal ulangan harian. Peneliti melakukan perbaikan pebelajaran dengan tujuan untuk meningkatkan hasil belajar fisika. Penelitian dilakukan selama dua siklus, setiap siklus terdiri dari dua pertemuan. Instrument data yang digunakan adalah test hasil belajar adan lembar pengamatan aktivitas guru dan siswa. Hasil penelitian ini menunjukan bahwa penerapan model belajar akooperatif Tipe Think Pair Share (TPS) dapat meningkatkan hasil belajar fisika siswa kelas XI IPA3 SMA Negeri 1 Tambusai Utara. Jumlah siswa yang mencapai KKM pada siklus I ada 19 siswa $(73,07)$ dan pada Siklus II meningkat menjadi 25 Siswa (96,15\% ). Hal ini disebabkan Karen model pembelajaran Kooperatif Tipe Think Pair Share dapat membuat siswa aktif dalam proses pembelajaran.
\end{abstract}

Kata Kunci : Model Pembelajaran Kooperatif Tipe Think Pair Share (TPS), Hasil Belajar, Pembelajaran Fisika

\section{PENDAHULUAN}

\section{A. Latar Belakang Masalah}

Ilmu Pengetahuan Alam (IPA) berkaitan dengan cara mencari tahu tentang fenomena alam secara sistematisd, sehingga IPA bukan hanya pengusaan kumpulan pengetahuan yang berupa faktafakta konsep, atau prinsip prinsip saja tetapi juga suatu proses penemuan (Depdiknas 2006). Penguasaan ilmu ilmu dasar ( Basic Science) pada siswa merupakan pondasi bagi perkembangan ilmu pengetahuan.

Fisika merupakan salah satu cabang ilmu pengetahuan alam yang mendasari perkembangan teknologi maju dan konsep hidup hyarmonis dengan alam. Perkembangna pesat dibidang teknologi informasi dan komunikasi dewasa ini dipicu oleh temuan dibidang fisika material melalui penemuan. (DEpdiknas 2006). Namun disisi lain mata pelajaran Fisika nsering dianggap sebagai mata pelajaran yang sulit dan menjadi hal yang menakutkan bagi sebagian siswa, bahkan sebagian guru, bahkan dianggap pelajaran yang membosankan.

Menyadari betapa pentingnya peranan mata pelajara Fisika, maka dalam proses pembelajaran sisika diperlukan metode, model bahkan strategi pembelajarn yang sedemikian rupa. Selama ini siswa sering mengalami kesulitan memahamin konsep konsep fisika dan sulit mengaplikasikan konspe tersebut dalam kehidupan sehari hari. Untuk itu perlu menciptakan pembelajaran yang mengasikkan, sehingga fisika dapat mudah dipahami oleh siswa, dan merupakan salah satu sarana yang dapat digunakan untuk dapat membentuk siswa berfikir ilmiah. Untuk memperoleh pemahaman dan penguasaan konsep fisika diperlukan usaha usaha yang harus dilakukan oleh guru.

Peranan guru juga tidak kalah pentingnya untuk meningkatkan hasil belajara siswa dalam proses pembelajaran. Pembelajaran merupakan komunikasi antar siswa dengan guru dan antara siswa dengan siswa. Komunikasi yang terjalin hendaknya merupakan komunikasi timbal balik, swehingga pesan yang disampaikan dalam bentuk materi pembelajaran berlangsung efektif serta dapat memecahkan masalah.

Pembelajaran merupakan suatu system terdiri dari berbagai komponen yang saling berhubungan satu sama lain. Komponen tersebut meliputi tujuan, materi, metode dan evaluasi. Keempat komponen tersebut harus diperhatikan oleh guru dalam memilih dan menentukan model odel pembelajaran apa yang 
akan diguakan dalam kegiatan pembelajaran ( Rusaman, 2012).

Kualitas pembelajaran Fisika dan hasil pembelajaran fisika di SMA Negeri 1 Tambusai Utara belum berlangsung secara optimal dan masih rendah, dikarenaka pembelajaran masih berpusat pada guru (Teacher Centered Learning). Guru lebih mendominasi pembelajaran, sehingga pembelajaran lebih monoton, sehingga siswa merasa cepat bosan, tersiksa dan tidak kreatif. Pada akhirnya tujuan pembelajaran tidak tercapai. Terbutki dari sebagian besar siswa memperoleh nilah yang tidak mencapai standar KKM yang ditetapkan yakni 75. Diperoleh fakta yang terjadi di kelas $\mathrm{XI}_{\text {IPA }}$ SMAN 1 Tambusai Utara bahwa dari 26 siswa ternyata ( $50 \%$ ) siswa tidak tuntas atau terdapat 13 sswa yang memperoleh nila diatas KKM pada kompetensi dasar menganaisis gerak lurus, gerak melingkar, dan gerak parabola dengan menggunakan vector.

Berdasarkan kondisi tersebut diatas, jika hal ini dibiarkan secara terus menerus, maka akan diperoeh dampak yang tidak baik, seperti hasil belajar Fisika tidak mencapai Nilsi dedusi KKM ysng telah ditetapkan.

\section{Rumusan Masalah}

Rumusan masalah dalam penelitian ini adalah : “ apakah penerapan model pembelajaran kooperatif tipe thinkp pair share (TPS) dapat meningkatkan hasil belajara fisika pada siswa kelas XI IPA 3 SMA Negeri 1 Tambusai Utara yahun pelajaran 2014/2015"?

\section{KAJIAN TEORI}

\section{Model Pembelajaran Kooperatif Tipe Think} Pair Share (TPS)

Pembelajaran Kooperatif Tipe Think Pair Share atau berpikir, berpsangan, berbagi adlaah merupakan jenis pembelajaran kooperatif yang dirancang untuk mempengaruhi pola interaksi siswa. Pembelajaran kooperatif Tipe Think Pair Share (TPS) diperkenalkan oleh Frank Lyman pada tahun 1985. Pembelajaran ini dirancang untuk mempengaruhi pola interaksi siwa ( Zainul Aqib, 2013).

Arends dalam Trianto

menyatakan bahwa Think Pair Share (TPS) merupakan suatu cara yang efektif untuk membuat variasi suasana diskusi dikelas.
Selanjutnya menurut Ibrahim, dkk (2000) Think Pair Share (TPS) atau ( berpikir, berpasngan , berbagi) merupakan jenis pembelajaran yang kooperatif yang dirancang untuk memperngaruhi pola interaksi siswa. TPS menghendaki siswa bekerja saling membantu dalam kelompok kecil (4-6 orang) dan lebih dirincikan oleh prenghargaan koopearatif, daripafa penghargaan individu.

Think Pair Share (TPS) digunakan untuk mengajarkan isi akademik atau untuk mengecek pemahaman siswa terhadap isi tertenru. Guru menciptakan interaksi yang daoat mendorong rasa ingin tahu, ingin mencoba, bersikap mandiri dan ingin maju. Guru memberi informasi, hanya informasi yang mendasaer aja sebagai pijakan bagi anak didik dalam mencari dan menemukan sendiri informasi lainnya. Atau guru menjelaskan materi dfengan mengaitkannya dengan pebgalaman dan pengetahuan anak sehingga memudahkan mereka memahami dan menanggapi pengalaman yang baru bahkan membuat anak didik mudah memusatkan perhatiannya.

Penerapan model pembelajaran Think Pair Share (TPS) diharapkan siswa dapat mengembangkan keteramplan berpikir dan menjawab dalam komunikasi antara satu dengan yang lain, serta bekerja saling membantu antar kelompok kecil. Hal ini sesuai dengna pengertia dari model pembelajaran TPS itu sendriri, sebagaimana yang dikemukaan oleh Anita Lie (2002) bahwa, TPS adalah pembelajaran yang memberika siswa untuk bekerja sama dengan orang lain. Dalam hal ini, guru berperan penting untuk membimbing siswa melakukan diskusi, sehingga terciptanya suasana belajar yang lebih hidup, aktip, kreatif, efektif, dan menyenangkan.

Menurut Ibrahim (2000) tahap utama dalam pebelajaran TPS sebagai berikut

Tahap 1 : Think ( Berpikir)

Guru mengajukan pertanyaan atau isu yang betrhubungan dengan pelajaran. Kemusian siswa diminta untuk memikirkan pertanyaan atau isu tersebut secar mandiri untuk beberaa saat.

Tahap 2 : Pair (berpasangan) 
Guru meminta siswa untuk berpasangan dengan siswa lain untuk mendiskusikan apa yang telah dipikirkanny bapada tahap pertama. Dalam tahap ini, setiap anggota pada kelompok membandingkan jawaban yang dianggap paling benar, paing myakinkan, atau paling unik.

Tahap 3 : Share ( berbagi)

Pada tahap akhir, guru meminta kepada pasangan agar berbagi dengan seluruh kelas tentang tentnag apa yang telah merteka bicarakan. Keteramilan berbagi dalam keseluruh kelas dapat dilakukan dengan menunjuk pasangna yang secara sukatrela bersedia mela0orkan hasil kelompok nya atau bergiliran pasangan dei pasangan hingga sekitar seeremoat pasangan telah mendapat kesematan untuk melaorkan.

Menurut Ibrahim, dkk (2000) terdapat kelebihan dan kekurangan model pembelajaran kooperatif TPS , kelebihan model TPS sebagai Berikut :

1. Meningkatkan pencurahan waktu dan tugas . penggunaan pembelajaran TPS menuntut siswa menggunakan waktunya untuk mengerjakan tugas tugas atau permasalahan yang diberikan oleh guru diawal pertemuan sehingga diharapkan siswa mampu memahami materi abika sebelum guru menyampaikan pertemuan selanjutnya.

2. Memperbaiki kehadiran. Tugas yang diberikan oleh guru padfa pertemuan sebelumnya untuk melibatkan siswa secara aktif dalam proses pembelajaran juga dimaksud agar siswa dapat selalu hadir pada setiap pertemuan. Sebab bagi siswa yg sekali tidak hadir maka siswa tersebut tidak mngerjakan tugas dan hal ini mempengaruhi hasil belajar mereka.

3. Angka putus sek9lah berkurang. Odel pembelajaran TPS diharapkan dapat memotivasi siswa dalam pembelajaran dengan mdel konvensional.

\section{METODE PENELITIAN}

\section{A. Subjek, Tempat, dan Waktu, Serta Pihak Yang Membantu Penelitian}

\section{Subjek}

Subjek penelitian pembelajaran ini adlah siswa kela XI IPA3 SMA Negeri 1 Tambusai Utara Kabupaten Rokan Hulu Tahun Pelajaran 2014/2015 yang berjumlah
4. Sikap apatis berkurang. Sebelum pembelajaran di mulai, kecenderungan siswa merasa malas dalam memluali belajar dikelas karena hanya mendengarkan apa yang disampaikan oleh guru dan menjawab semua yang ditanyakan guru. Dengan melibatkan siswa secara aktif dalam proses pembelajaran, model pembelajaran TPS akan lebih menarik dan todak monoton dibandingkan metode konvensional.

5. Penerimaan terhadap individu lebih besart. Dalam model pembelajaran konvensional siswa yang aktip didalam kelas hanyalah siswa tertentu yang benar benar rajin dan cepat dalam menerima materi yang disampaikan oelh guru sedangkan siswa yang lainya hanya menjadi pendengar materi. Dengan pembelajarn TPS hal in diminimalisir sebab semua siswa akan terlibat denga permasalahan yang diberikan guru.

6. Hasil belajar lebih meningkat. Parameter dalam pembelajaran adalah hasil belajar yang diraih siwa. dnegan pembelajaran TPS perkembangan hasil belajar siswa dapat diidentifikasi secara bertahap sehongga pada akhirnya pembelajaran hasil yang diperoleh siswa dapat lebih optimal.

7. Meningkatkan kebaikan budi, kepekaan, dan toleransi. System kerja sama yang diterapkan dalam model pembelejaran TPS menuntu siswa untuk dapat bekerjasama dalam tim sehingga siswa dituntut untuk dapat belajar berempati, menerima pendapt lain, atau mengakui secara sportif jika pendapatnya tidak diterima.

Kelemahan model pembelajaran TPS adlah pembelajaran yang baru diketahui, kemugkijnan yang dapat timbul adalah sejumlah siswa bingung, sebagia kehilangan rasa percaya diri, saling mengganggu antar siswa ( Ibrahim, $2000 \quad$ ).

26 orang terdiri dari 7 siswa laki laki dan 19 siswa perempuan. Penelitian ini dikhususkan pada mata pelajaran Fisika.

\section{Tempat}

Penelitian perbaikan pebelajaran dilaksanakan di SMA Negeri 1 Tambusai Utara Kabupaten Rokan Hulu. peneliti 
mengambil tempat disekolah ini karena peneliti meruakan guru disekoah tersebut.

\section{Waktu}

Peneitian dilaksanakan pada semester ganjil tahun pelajaran 2014/2015.

Adapun waktu penelitian dapat dilihat pada table 3.1 berikut ini.

Table 1. Jadwal Pelaksanaan Perbaikan Pembelajaran

\begin{tabular}{|c|c|c|c|c|}
\hline $\begin{array}{c}\text { N } \\
\text { o }\end{array}$ & $\begin{array}{c}\text { Hari/Tang } \\
\text { gal }\end{array}$ & $\begin{array}{c}\text { Wakt } \\
\mathrm{u}\end{array}$ & $\begin{array}{c}\text { Mata } \\
\text { Pelajar } \\
\text { an }\end{array}$ & Ket \\
\hline 1 & $\begin{array}{c}\text { Selasa / 4 } \\
\text { maret } \\
2014\end{array}$ & $\begin{array}{c}07.3 \\
0-\end{array}$ & Fisika & $\begin{array}{c}\text { Siklus I } \\
\text { Pertemu } \\
\text { an }\end{array}$ \\
& & 5 & & \\
\hline 2 & Rabu/ 5 & 07.3 & Fisika & Siklus 1 \\
& maret & $0-$ & & $\begin{array}{c}\text { pertemus } \\
\text { an 2 }\end{array}$ \\
& 2014 & 09.0 & & \\
\hline 3 & Selasa / 11 & 07.3 & Fisika & Siklus II \\
& maret & $0-$ & & pertemua \\
& 2014 & 09.4 & & n 1 \\
& & 5 & & \\
\hline 4 & Rabu/ 12 & 07.3 & Fisika & Siklus II \\
& maret & $0-$ & & pertemua \\
& 2014 & 09.0 & & n 1 \\
& & 0 & & \\
\hline
\end{tabular}

\section{B. Desain Prosedur Perbaikan \\ Pembelajaran}

Penelitian perbaikan pembeajaran ini direncanakan melalui 4 tahap, yaitu perencanaa (Planning), pelaksanaan tindakan (action), pengamatan ( Observation), dan refleksi (reflection). Prosedur pelaeksanaan Penelitian tindakan Kelas (PTK) dapat dilihat pada gambar 3.1 berikut:

Gambar 1.

Prosedur Penelitian Kelas (PTK)
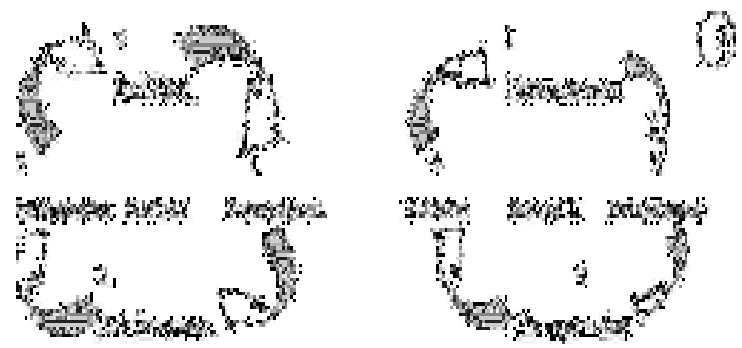

Adaptasi Prosedur Penelitian Tindakan Kelas ( Suyadi, 2012)

1. Rencana Kegiatan Perbaikan Pembelajaran
Rencan pelaksanaan perbaiakn pembelajaranFisika dikleas XI IPA ${ }_{3}$ SMA Negeri 1 Tambusai Utara Meliputi:

- Mengadakan pertemuan dengan teman sejawat, berdiskusi tentangn persiapan penelitian.

- Menyiapkan lembar observasi Aktivitas guru, lembar observasi aktivitas siswa.

- Menyiapkan alat evaluasi

- Menyiapkan rencana pelaksanaan perbaikan pembelajaran (RPP)

2. Pelaksanaan Tindakan Perbaikan

Pembelajaran

Pelaksanaan tindakan perbaikan pembelajaran dilaksanakna dalam dua siklus dimana setiap siklus nya terdiri dari dua kali pertemuan, pelaksanaan penelitian selama siklus berlangsung menggunakan model pembelajaran kooperatif tipe Think Pair Share (TPS) melalui kegiatan awal, kegiatan inti, dan kegaiatan penutup. Adapun kegiatan pelaksanaan perbaikan pembelajaran diuraikan dengan langkah langah dibawahn ini:

- Pendahuluan

- Mengkoordinasi siswa untuk belajar

- Memberi persepsi dan motivasi

- Menyampaikan indicator dan kompetensi yang diharapkan

- Kegiatan Inti

- Guru memnta siswa duduk pada kelompok yang telah ditentukan

- Guru mrnyampaikan materi pembelajaran secara umum

- Guru membagikan lembar tugas yang berisi pertanyaan kepada siswa

Tahap Think : siswa diminta dan diberi kesempatan oleh guru untuk memikirkan dan menjawab pertanyaan melalui tugas yang diberikan guru tersebut secara mandiri untuk beberapa saat.

Tahap pairing

- Guru meminta siswa berpasangan dengan siswa lain didalam kelompoknya untuk mendeiskusikan apa yang telah dipikirkan atau apa yang telah dikerjakan terhadap tugas yang telah diberikan guru.

- Siswa beriteraksi dengan pasangan untuk berinteraksi dengan pasangan 
untuk mendiskusikan hasil kerjanya dengna cara membandingkan jawaban atau hasil pemikiran siswa dengan meanentukan jawaban yang dianggap paling benar, paling meyakinkan atau paling unik.

- Guru membuimbing siswa dalam pasangannya dan mengarahkan jika diantaranya pasangan siswa ditemukan perbedaan pendapat.

- Guru melakukan peninjauan pada tiap tiap pasangan.

Tahap Share

- Siswa yang telah berpasngan diminta kembali bertemu dalam kelompok masing masing

- Guru meminta kepada pasangna untuk melaporkan hasil diskusinya dan pasangan yang lain dan memberikan tanggapan.

- Guru memandu jalanya setiap pasangan demi pasangan hingga sekita seperempat pasangan telah mendapat kesempatan untuk melaporkan hasil disjusinya.

- Guru melakukan Tanya jawab pada siswa tentang hal hal yang belum diketahui siswa

- Guru bersama siswa melakukan Tanya jawab meluruskan kesalahan pemahaman memberikan penguatan.

- Kegiatan akhir/ penutup

- Guru bersama siswa menyimulkan materi pelajaran

- Guru memberikan evaluasi

- Guru meberikan PR

Pada tahap pengamatan dilakukan dengna mengamati aktifitas guru dan siswa selama proses pembelajaran berlangsung.

- Lembaran observasi aktivitas guru terdiri dari :

- Menyampaiakn apersepsi dan motivasi

- Menyampaikan tujuan pembekajaran

- Menyampaiakan materi pembelajaran

- Mengorganisasi siwa dalam kelompok yang telah ditentukan

- Membagika tugas kepada siswa

- Membimbing siwa untuk untuk memikirkan dan mngerjakan tugas

- Meminta siswa berpasangan dengan siswa lain untuk mendiskusikan tugas yang telah diberikan
- Membimbing siwa supaya berani mengemukakan pendapat

- Membimbing siswa dlam diskusi kelompok apabila ditemukan perbedaan pendapat

- Guru membimbing presentasi siswa

- Guru membimbing siswa menyimpulkan pembelajran

- Guru memberikan evaluasi.

- Guru memberikan pekerjaan rumah

- Lembaran observasi aktifitas siswa terdiri daria;

- Keaktifan siswa dalam mngerjakan tugas

- Keaktifan siswa dalam bertanya

- Kerja sama siswa dengan pasangan nya masing masing

- Keaktifan siswa dalam diskusi

- Tanggung jawab siswa terhadap hasil diskusi

\section{Refleksi}

Refleksi berarti penilaian diri yang dilakukan diri sendiri. Hal ini berarti guru yang melakukan kegiatan pembelejaran dikelas harus menilaindiri sendiri tentang kemampuan mengajar yang dimilikinya. Pada saat kegiatan perbaikan pembelajaran dilaksanakan, guru mebawa lembar refleksi tersebut ke kelas dengan kenyataan yang dilakukan.

Untuk melakukan pengisian lembar refleksi ini, guru harus jeli melihat dari segala fakta yang ditemukanya pada saat kegiatan mngajar. Jika pada saat mengajr siwa banyka ynag tidak memperhatikan berate bias saja penyebabnya pengelolaan kelas kurang maksimal.

Hasil lembaran refleksi ini berupa kekuatan dan kelemahan sealama proses pembelajaran dapat digunakan untuk merencanaakn kegiatn perbaikan tindakan pada siklus berikutnya.

\section{Instrumen Prngumpul Data}

Instrument pengumpulan data yang digunakan pada penelitian ini adalah berupa tes hasil belajar fisika yantg dilakukan pada setiap akhir pembelajaran disetiap siklusnya, sedangkan aktivitas guru dan siswa mrnggunakan lembar pengamatan aktivitas siswa. 
D. Teknik Pengumpulan Data/ Instrumen

Teknik pengumpulan datan daalam peneltian ini adlah :

a. Teknik tes, teknk yang dilakukan untuk mengumpulkan data kuantitatif dalam penenlitian di dikumpulkan dengan cara memberikan ulangan harian yang telah direncanankan setelah berakhir elas.

b. Teknik pegammatan, pengamatan dalam penelitian ini diakukan untuk mengamati aktivitas guru dan siswa selam aprses pembelajaran dengan cara mengisi lembar pengamatan yang telah disiakan untuk setiap kali pertemuan.

\section{E. Tekhnik Analisis Data}

Teknik analsisi ata yang dugunakan adalah analaisis statistic deskriotif untuk memperoleh gambaran data tentang hasil tes belajar Fisika, aktivitas siswa dan guru. Menurut Slamet (2010) analisis statistic desktriptif dapat digunakan untuk mengolah karakteristik data yang berkaitan dengan menjumlah, merata rata, mencari titik tengah, dan ikuti alur berfikirnya ( grafik, table, chart).

Analisis data hasil pengamatan diperoleh dari lembar pengamatan aktifitas guru dan sisewa selama prose pembelajaran berlangsung dengan melihat kesesuaian antara rencana atau indicator yang ada di lembar pengamatan saat pelaksanaan pembelajaran.

Analisis data tentang aktivitas guru dan siswa diamati selama proses pembelajaran berlangsung dengan tujuuan untuk melihat bagaimana guru melaksanakan proses pembelajaran dan bagaimana siswa mengikuti proses pembelajaran.

Analisi data tentang indicator dilakuka dengan melihat hasil belajar siswa secara individual yang diperoleh dari ualangan harian sudah mencapai $70 \%$ dari skor maksimal untuk setiap indicator.
Persentase

ketuntasan

indicator

dirumuskan :

$$
\mathrm{S}=\frac{R}{N} X 100 \%
$$

Keterngan:

$\mathrm{S}=$ persentase ketercapaian i8ndikator'

$\mathrm{R}=$ skor yang diperoleh siswa

$\mathrm{N}=$ skor maksimal

Untuk mengetahui hasil perbaikan pembelajaran, data data dikumoulkan melalui tes pada akhir pembelajaran. Tes berupa soal soal dalam lembar kerja siswa, siswa yang mengikuti tes dinyatakan tuntas belajar apabia mendapat nilai 70 keatas sesuai engna KKM yang telah ditentukan.

Untuk mengukur hasil belajar siswa digunakan rumus:

$$
\text { Nilai }=\frac{\text { skor perolehan }}{\text { skor maksimal }} \times 100
$$

Setelah diperoleh nilai hasil bekajar kemudian dihitung ketuntasan belajar secara klasika. Indicator ketuntasan belajar secara klasikal apabila $75 \%$ siswa dari jumlah secara akeseluruhan dinyatakan tuntas belajar. ketuntasan secara kalasikal dihitung dengan menggunakan rumus :

Pencapaian klasikal

$$
=\frac{\text { jumlah siswa yang tuntas }}{\text { jumlah seluruh siswa }} \times 100 \%
$$
deduai dengan KKM DI sma Negeri 1 Tambusai Utar adalash $\geq 70 \%$ dari jumlah mendapat nilai $\geq 70$.

Analisis data nilai perkembangan dan penghargaan dilakukan berdasarkan skor ulangan harian dan skor dasar yang edimiliki oleh tiap individu. Tujuan dari nilai pengembangan dan penghargaan kelompok adalah untuk melhat seberapa besar siswa memberikan nilai maksimum bagi kelompok. Dengan memperoleh gambaran maka peaneliti dapat mengetahui apakah tindakan yang diterapkan berhasil atau tidak berhasil.

Menurut suyanto dalam Nihayati (2008) menyatakan bahwa apabila skor hasil belajar siswea setelaj tindakan lebih baik daripada sebelum tindakan maka dapat dikatakan bahwa tindakan berhasil, akan tetapi jika belum adanya baedanya dan bahkan lebih buruk maka tindakanya belum berhasil. 
HASIL PENELITIAN DAN PEMBAHASAN A. Analisis Hasil Penelitian

\section{Analisis Hasil Pengamatan}

\subsection{Siklus I ( satu)}

Pengamatan siklus I pertemuan pertama : aktivitas gru beklum semua terlaksana, salah satunya guru terlupa menyamoaikan tujuan pembelajaran yang ingin di capai, aktivitas siswa kurang aktif dan suasana kelas rebut dalam susasana diskusi karena siswa belum terbiasa belajar dengan pembelajaran kooperatif tipe Think Pair Share (TPS) dan belum belum memahani langkah langkah pembelajaran dan masih terlihat ada siswa yagn hanya melihat temanya bekerja. Ketika mengerjakan tugas dengan pasangan nya masih didominasi oleh siswa yang pintar. Sedangkan siswa yang lain kurang berpartisipasi, siswa yang aktip pembelajaran belum mencapai maksimal.

Pengamatan kedua siklus I, pertemuan kedua hasil pengamatan tanggal 17 September 2014 bahwa aktivitas guru dalam melaksanakan pembelajaran kooperatif tipe Think Pair Share (TPS) menunjukkan bahwa aktivitas guru sudah mulai dengan perencanaan pembelajaran, sedangkan aktivitas siwa pada waktu pembelajaran berlangsung masih kurang aktif hal ini di tunjukan dari siswa masih main main dan kurang aktip dalam mengerjakan tugas dan kurang aktif dalam bekerjasama antar pasanagnaya. Pada saat persentasi masih ada pasangan siswa yang telah tidak mau tampil kedepan, kemudian siwa yang memberi tanggapan juga masih sedikit.

\subsection{Siklus II ( dua )}

tipe Think Pair Share (TPS) sudah sesuai dengan rencaa pembelajaran yang telah dibuat.

\section{Analisis Data Hasil Belajar}

\section{1 analisis hasil ulagan hariasn}

Berdasarkan hasil ulangan harian 1 dan ulangan haria 2 yang diperoleh siswa sesudah tindakan, maka jumlah siswa yang mencapai KKM indicator dapat dilihat pada table dibawah ini.

Tabel 2. Keterampilan KKM indicator pada ulagan harian I

\begin{tabular}{|c|c|c|c|c|}
\hline No & Indicator Ketercapaian & $\begin{array}{l}\text { No } \\
\text { Soal }\end{array}$ & $\begin{array}{c}\text { Jumlah Siswa yang } \\
\text { mencapai KKM }\end{array}$ & $\%$ \\
\hline \multirow[t]{5}{*}{1} & \multirow{5}{*}{$\begin{array}{l}\text { - } \text { menganalisis hubungan } \\
\text { antara gaya grafitasi dengan } \\
\text { massa benda dan jarak } \\
\text { - menghitung resultan gaya } \\
\text { grafitasi benda titik dalam } \\
\text { satu system }\end{array}$} & 1 & 26 & 100 \\
\hline & & 2 & 24 & 92,30 \\
\hline & & 3 & 10 & 38,46 \\
\hline & & 4 & 19 & 73,07 \\
\hline & & 5 & 14 & 53,84 \\
\hline 2 & - membandingkan percepatan & 6 & 21 & 80,76 \\
\hline
\end{tabular}




\begin{tabular}{|l|l|c|c|c|}
\hline & grafitasi dan kuat medan & 7 & 20 & 76,92 \\
\cline { 2 - 4 } & $\begin{array}{l}\text { grafaitasi pada kedudukan } \\
\text { yang berbeda }\end{array}$ & 8 & 15 & 57,69 \\
\cline { 2 - 4 } & 9 & 22 & 84,61 \\
\cline { 2 - 4 } $\begin{array}{l}\text { menganalisis gerak planet } \\
\text { dalam tata surya } \\
\text { berdasarkan hokum keppler }\end{array}$ & 10 & 13 & 50,00 \\
\hline
\end{tabular}

Berdasarkan tabel 2 diatas dapat dilihat bahwa pada ulangan harian I tersebut dapat dijelaskan tentang ketercapaian KKM indicator yang dicapai siswa. Pada indicator I : menganalisis hubungan antara gaya grafitasi dengan massa benda dan jaraknya dan menghitung resultan gaya grafitasi benda titik dalam satu sitem, terdiri dari lima soal, unutk soal no 1 ada 26 siswa yang mencapai KKM (100\%). Unutk soal no 2 terdapat 24 siswa atau 92,30 \% yang mencapai KKM, berabti ada 1 siswa atau $(3,84 \%)$ yang tidak mencapai KKM. Selanjutnya untuk soal no. 3 ada 10 siswa yang mencapai KKM atau $(38,46 \%)$ siswa yang tidak mencapai KKM berjumlah 16 siswa atau $(61,53 \%)$ dikarenakan belum memahami indikatorn tersebut, selanjutnya untuk nomor 5 terdapat 19 siswa $(73,07 \%)$ sedangkan pada soal no 5 terdapat 14 siswa dari 26 siswa yang mencapai KKM, ada $(46,15 \%)$ dari siswa yagn tidak mencapai KKM.

Untuk indicator II : membandingkan percepatan grafitasi dan kuat medan grafitasi pada kedudukannya yang berbeda. Indicator II terdiri dari 5 soal yakni soal nomor 6 sampai 10. Untuk soal no 6 ada ada 21 siswa atau (80,76\%) yang mencapai KKM. Dan soal no 7 ada 20 siswa atau $(76,92 \%)$ yang mencapai KKM, selanjutnya untuk soal no 8 terdapat 15 siswa atau $(57,69 \%)$ dari 26 siswa yang mencapai KKM, berarti 11 siswa (42,31\%) tidak mencapai KKM dikarenakan siswa belum dapat menyelesaikan soal tersebut. Soal nomor 9 ternyata mampu di jawab oleh 22 siswa dengan benar tetapi soal no 10 hanya 13 siswa atau $50 \%$ yang mencapai KKM.

Tabel 3. Ketercapaian KKM Indikator pada Ulangan Harian II

\begin{tabular}{|c|c|c|c|c|}
\hline No & Indicator Ketercapaian & $\begin{array}{l}\text { No } \\
\text { Soal }\end{array}$ & $\begin{array}{c}\text { Jumlah Siswa yang } \\
\text { mencapai KKM }\end{array}$ & $\%$ \\
\hline \multirow[t]{5}{*}{1} & \multirow{5}{*}{$\begin{array}{l}\text { mengidentifikasi sifat } \\
\text { benda elastis, tegangan, } \\
\text { regangan dan modulus } \\
\text { elastisitas }\end{array}$} & 1 & 26 & 100 \\
\hline & & 2 & 25 & 96,15 \\
\hline & & 3 & 23 & 88,46 \\
\hline & & 4 & 23 & 88,46 \\
\hline & & 5 & 21 & 80,76 \\
\hline \multirow[t]{5}{*}{2} & \multirow{5}{*}{$\begin{array}{l}\text { - } \text { mendeskripsikan gaya pada } \\
\text { benda elastis dan tetapan } \\
\text { pegas berdasarkan grafik } \\
\text { - menerapkan konsep pegas } \\
\text { dan prinsip hokum hooke } \\
\text { - menganalsiis susunan pegas } \\
\text { seri dan parallel }\end{array}$} & 6 & 24 & 92,30 \\
\hline & & 7 & 23 & 88,46 \\
\hline & & 8 & 24 & 92,30 \\
\hline & & 9 & 21 & 80,76 \\
\hline & & 10 & 21 & 80,76 \\
\hline
\end{tabular}

Berdasarkan pada tabel 3 diatas dapat dilihat bahawa terjadi peningkatan siswa yang mencapai KKM, walapun masih ada siswa yang belum mencapai KKM. Darin tabel 4.2 diperoleh data bahwa pada indicator I, unutk soal nomor 1 semua siswa menjawab benar (100\%) dan soal no 2 ada 25 siswa $(96,15 \%)$ yang menjawab benar, soal nomor 3 dan soal nomor 4 ternyata dari 26 siswa ada $23(88,46 \%)$ siswa mencapai $\mathrm{KKm}$,sementara unutk nomor 5 ada 21 siswa $(80,76 \%)$ mencapai KKM. Selanjutnhya pada indicator II, terdiri dari 5 soal yakni soal nomor 6 ada 24 siswa (92,30\%), unutk soal nomor 7 ada 23 siswa (88,46\%) mencapai KKM, unutk soal no 8 ada 24 siswa (92,30\%) mencapai KKM, selanjutnya untuk soal nomor 10 ternyata ada 21 siswa $(80,76 \%)$ yang mencapai KKM. 


\subsection{Analisis Nilai Perkembangan Kelompok}

Hasil belajar yang diperoleh masing masing siswa akan memperoleh nilai perkembangan individu yang akan disubangkan kepada kelompoknya. Nila perkembangan dihitung pada siklus pertama setelah ulangan harian, dan siklus kedua setelah ulangan harian kedua. Nilai perkembangan siklus I dihitung berdasarkan selisish skor dasar dengan skor nilai ulangan harian I, sedangkan nilai perkembangan siklus kedua dihitung selisish skor ulangan harian 1 dengan skor nilai ulangan harian 2.

Untuk melihat pearkembangan individu dan penghargaan kelompok pada siklus I dan siklus II dapat dilihat pada tabel berikut :

Tabel 4. Perkembangan siswa pada siklus I dan siklus II

\begin{tabular}{|c|c|c|c|c|}
\hline \multirow{2}{*}{$\begin{array}{c}\text { Nilai } \\
\text { perkembangan }\end{array}$} & \multicolumn{2}{|c|}{ Siklus I } & \multicolumn{2}{c|}{ Siklus II } \\
\cline { 2 - 5 } & $\begin{array}{c}\text { Jumlah } \\
\text { Siswa }\end{array}$ & Presentase & $\begin{array}{c}\text { Jumlah } \\
\text { Siswa }\end{array}$ & Presentase \\
\hline 5 & 1 & $3,85 \%$ & - & - \\
\hline 10 & 0 & - & - & - \\
\hline 20 & 13 & $50,00 \%$ & 4 & $15,38 \%$ \\
\hline 30 & 12 & $46,15 \%$ & 22 & $84,62 \%$ \\
\hline
\end{tabular}

Dari tabel 4 dapat dilihat bahwa persentase siswa dalam menyumbangkan nilai perkembangan siswa sikus I dan siklus II. Dari tabel terlihat adanya penigkatan setiap individu untuk menyumbangkan nikai pada kelompok.

Untuk melihat penghargaan distiap klompok dapat dilihat pada tabel dibawah ini.

Tabel 5. Penghargaan untuk setiap kelompok pada siklus I dan siklus II

\begin{tabular}{|c|c|c|c|c|}
\hline \multirow{2}{*}{$\begin{array}{c}\text { Nilai } \\
\text { kelompok }\end{array}$} & \multicolumn{2}{|c|}{ Siklus I } & \multicolumn{2}{c|}{ Siklus II } \\
\cline { 2 - 5 } & $\begin{array}{c}\text { Skor } \\
\text { kelompok }\end{array}$ & Penghargaan & $\begin{array}{c}\text { Skor } \\
\text { Kelompok }\end{array}$ & Penghargaan \\
\hline TPS -1 & 25,00 & Super & 30,00 & Super \\
\hline TPS-2 & 25,00 & Super & 25,00 & Super \\
\hline TPS-3 & 18,75 & Hebat & 30,00 & Super \\
\hline TPS-4 & 25,00 & Super & 30,00 & Super \\
\hline TPS-5 & 25,00 & Super & 30,00 & Super \\
\hline TPS6 & 25,00 & Super & 26,66 & Super \\
\hline
\end{tabular}

Berdasarkan tabel 5 dapata diperoleh gambaran bahwa hasil belajar yang diperoleh individu akan mendapat perkembangan individu yang disumbangkan pada kelompoknya, selanjutnya tiap kelompok akan memperoleh penghargaan kelompok. Dari tabel 4.4 menunjukan bahwa penghargaan yang diperoleh masing masing kelompok diskilus II mengalami peningkatyan dari siklus I, ini berarti bahawa terjadi peningkatan nikai individu yang berpengaruh untuk kelompoknya.

\section{Analisis Keberhasilan Tindakan}

Peningkatan hasiln belajar siswa kelas XI IPA 3 SMA Negeri 1 Tambusai Utara untuk tindakan siklus I dan siklus II dapat dilihat tabel distribudsi frekuensi nilai hasil belajar dibawah ini. 
Tabel 6. Daftar Distribusi Frekuensi Nilai Hasil Belajar IPA

\begin{tabular}{|c|c|c|c|}
\hline & \multicolumn{3}{|c|}{ Frekuensi (F) } \\
\cline { 2 - 4 } & Skor Dasar & Ulangan Harian I & Ulangan Harian II \\
\hline $29-40$ & 4 & 2 & - \\
\hline $41-52$ & 2 & 1 & - \\
\hline $53-64$ & 7 & 4 & 1 \\
\hline $65-76$ & 11 & 7 & 7 \\
\hline $77-78$ & 2 & 11 & 18 \\
\hline $88-100$ & - & 1 & 26 \\
\hline Jumlah Siswa & 26 & 19 & 25 \\
\hline $\begin{array}{c}\text { Jumlah siswa } \\
\text { yang mencapai } \\
\text { KKM 70 }\end{array}$ & 13 & & $96,15 \%$ \\
\hline $\begin{array}{c}\text { \% Jumlah siswa } \\
\text { yang mencapai } \\
\text { KKM 70 }\end{array}$ & $50 \%$ & $73,07 \%$ & \\
\hline
\end{tabular}

Berdasarkan data pada tabel 6 jika ditampilkan dalam bentuk diagram batang adalah sebagai berikut:

Gambar 2. Grafik Distribusi Frekuensi Nilai Hasil Belajar Fisika

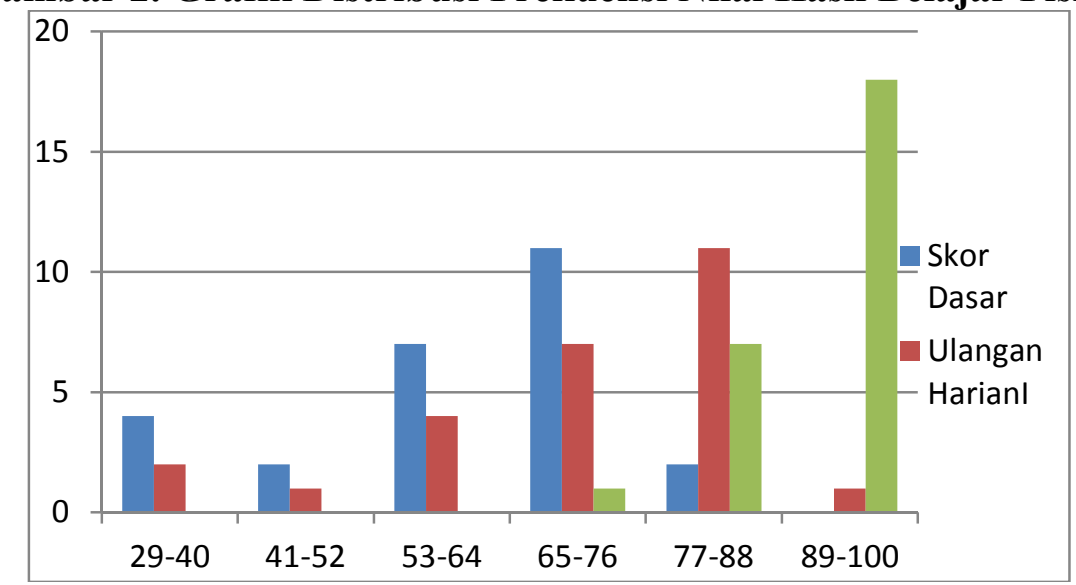

Dari grafik distribusi frekuensi hasil belajar siswa tersebut dapat dilihat bahwa skor dasar siswa yang belum mencapai KKM ada 13 siswa (30\%) sementarab pada siklus I turun menjadi 7 siswa ( $26,92 \%$ ) yang tidak mencapai KKM, sedangkan pada siklus II terdapat 1 siswa ( $3,84 \%$ ) yang tidak mencapai KKM, sebaliknya jumlah siswa yang mencapai KKM mengalami peningkatan dari skor dasar, ulangan harian I dan ulangan harian II.

Frekuensi atau jumlah siswa yang mencapai KKM sebelum tindakan ada 13 orang siswa atau (50\%). Pada ulangan harian I meningkat menjadi 19 siswa $(73,07 \%)$ yang mencapai KKM, sedangkan pada ulangan harian II kembali mengalami peningkatan dari siklus I menjadi 25 orang siswa atau $(96,15 \%)$ yang mengalami KKM.

Dari tabel dapat disimpulkan bahwa siswa yang mencapai KKM pada ulangan haria I jumlah siswa lebih banyak dari skor dasar. Kemudian siswa yang mencapai KKM pada ulangan harian II jumlahnya lebih banyak dari ulangan harian I. edngna demikian dapat disimpulkan bahwa terdapat peningkatan jumlah siswa yang mencapai KKM sesudah tindakan, tau dapat dikatakan tindakan berhasil. Hal ini sesuai dengna pendapat Suyanto dalam Nihayati (2008). Bahwa apabila nilai hasil belajar siswa setelah tindakan lebih baik maka dapat dikatakan berhasil, akan tetapi jika tidak ada bedanya atau lebih buruk maka tindakan beum berhasil. Dengna demikian dapat 
disimpulkan bahwa penerapan pembelajaran koopearatif tipe Think Pair Share (TPS) dapat meningkatkan hasil belajar Fisika.

\section{B. Pembahasan hasil penelitian}

Berdasarkan hasil analisis data yang telah dideskripsikan menunjukan bahwa hasil belajar fisika mengalami peningkatan dari siklus I dan Siklus II. Terjadinya peningkatan hasil belajar fisika yang diperoleh siswa didukung menigkatnya aktivitas gurundalam menciptakan suasana pembelajaran yang lebih menarik, pembelajaran yang lebih sesuai denga tujuan pembelajaran fisika dan kebutuhan belajar siswa dalam pembelajaran Fisika.

Penerapan pempelajaran kooperatif tipe Think Pair Share (TPS) di kelas XI IPA 3 SMA Negeri 1 Tambusai Utara, pada awalnya mengalami kendala kendala, hal ini disebabkan karena siswea beum terbiasa dengan model pembelajaran ini, karena siswa terbiasa dengan metode ceramah. Namun setelah guru menjelaskan langkah langkah pembelajaranya siswa berangsur angsur aktif dalam pembelajaran.

Berdasarkan deskripsi hasil penelitian tentang analisis hasil pengamatan, analisis hasil belajar dan analisis keberhasilan tindakan dapat diperoleh gambaran bahwa penerapan pembelajaran kooperatif tipe Think Pair Share (TPS) dari kegiatan disiklus I mengalamipeningkatan diskusi siklus II, aktivitas guru dan aktivitas siswa selama proses pembelajaran berlangsung mengalami perubahan kearah yang lebih baik. Di siklus I, memang keaktifan siswa belum optimal, namun pada siklus II siswa sangat antusias dan aktif dalam proses pembelajaran bahkan suiswa tidak malu malu bertanya jika ada materi yang belum mereka pahami.

Selama proses pembelajaran berlangsung nilai perkembangannya individu yang akan disumbagkan ke nilai kelompoknya juga mengalami peningkatan. Dengan meningkatknya nilai perkembangan individu maka predikat yang diperoleh setiap kelompok super. Pada siklus II diperoleh gambaran bahwa dari enam kelompok terdapat semua kelompok memiliki predikat kelompok super.

Jumlah siswa yang mencapai KKM pada siklus II juga mengalami peningkatan jika dibandingkan dengan siklus I. hal ini menunjukkan kualitas proses pembellajaran sisika semakin baik dengan menerapkan pembelajaran kooperatif tipe Think Pair Share (TPS). Meskipun pada saat pelaksanaan ada beberapa kelemahan yang ditemukan dinataranya pada peartemuan pertmanya di siklus I, ditemukan sebagian besar siswa masih bingung dan tidak bekerja sama dengan pasangannya, ini dikarenakan siswa belum terbiasa dengan kooperatif tuipe Think Pair Share (TPS). Kekuagan ini diperbaiki pada siklus II, sehingga di siklus II siswa sudah mersa senang dan aktif dalam diskusi, memiliki keberanian dalam mempresentasikan hasil diskusinya. Hal ini sependapat dengan Lie (2002) bahwa Think Pair Share (TPS) merupakan pembelajaran yang memberi siswa kesempatan untuk bekerja sendiri dan bekerja dengan orang lain.

Berdasarkan uraian diatas dapat disimpulkan penerapan model pembelajaran kooperatif tipe Think Pair Share (TPS) dapat meningkatkan hasil belajar siswa kelas XI IPA 3 SMA Negeri 1 Tambusai Utara.

\section{SIMPULAN}

Berdasarkan analisis hasil penelitian dan pembahasan dapat disimpulkan bahwa:

1. Penerapan pembelajaran kooperatif tipe Thin Pair Share (TPS) dapat meningkatkan ahsil belajar fisika pada siswa kelas XI IPA 3 SMA Negeri 1 Tambusai Utara.

2. Terjadi peningkatan jumlah siswea yang mencapai KKM yaitu 13 siswa 50\% (sebelum tindakan), pada siklus I diperoleh 19 siswa $(73,07 \%)$ dan meningkat di diklus II menjadi 25 siswa $(96,15 \%)$.

3. Predikat penghargaan kelompok yang diperoleh masing masing kelompok mengakami peningkatan disiklus kedua.

\section{DAFTAR PUSTAKA}

Agib, Z. (2013). Model-Model, Media \& Strategi Pembelajaran Konstektual. Bandung : Irama Widya.

Arikunto, S. Dkk (2010). Penelitian Tindakan Kelas. Jakarta : Bumu Asara.

Dariyanto \& Rahardjo, M. (2003). Model Pembelajaran Inovatif. Yogyajarta : Grava Media. 
Depdiknas. (2006). KTSP. Jakarta : Depdiknas. Dimyati \& Mudjiono. (2009). Belajar dan Pembelajartan. Jakarta : Rineka Cipta.

Ibrahim, M. Dkk (2000). Pembelaran Kooperatif. Universitas Negeri Surabaya.

Lie, A. (2008). Cooperative Learning mempraktikkan Kooperatif Learning di Ruang-Ruang Kelas. Jakarta : Garsindo.

Nihayati. (2008). Upaya Meningkatkan Hasil Belajar Matematika Melalui Pembelajaran Yang Diawali dengan Pembelajaran Soal Cerita Pada Siswa Kelas V SD Negeri 007 SEKIP HULU, Skripsi.

Rusman. (2012). Model-Model Pembelajaran Mengembangkan Profesionalisme Guru. Jakarta: Rajawali Pers.
Slavin (2009). Cooperative Learning Theory Reseach And Practice. Boston Allyn and Bacon Publisher.

Suprijono, A. (2013). Cooperative Learning. Yogyakarta : Pustaka Pelajar.

Syah,M. (2012). Psikologi Belajar. Jakarta : Dirjen Dikdasmen.

Suyadi. (2012). Buku Panduan Guru Profesional Penelitian Tindakan Kelas dan Penelitian Tindakan Sekolah. Yogyakarta : Penerbit Andi.

Trianto (2009). Mendesain model Pembelajaran Inovatif_Progresif : KOnsep Landasan Dan Implementasinya Pada Kurikuum Tingkat Satuan Pendidikan (KTSP). Jakarta : Kencana.

Tani Redja, Tukiran, Dkk. (2012). Penelitian Tindakan Kelas untuk Pengembangan Profesi Guru Praktik, Praktis dan Mudah. Bandung : Alfa Beto. 